\title{
Water Quality from the Purification Unit of Thiakhar (Diourbel, Senegal) and Impact of Discharges from Treatment on Water Resources
}

\author{
Cheikh Hamidou Kane ${ }^{1}$, Moustapha Diène ${ }^{2}$, Baba Sarr ${ }^{3}$ \\ ${ }^{1}$ Laboratory of Mechanics and Modeling-Sciences of Engineering of Thies, Thies, Senegal \\ ${ }^{2}$ Department of Géology, FST-UCAD, University Cheikh Anta Diop of Dakar, Dakar, Senegal \\ ${ }^{3}$ Laboratory of Geology, IFAN, University Cheikh Anta Diop of Dakar, Dakar, Senegal \\ Email: cheikh.kane@univ-thies.sn
}

Received September 11, 2013; revised October 13, 2013; accepted November 14, 2013

Copyright (C) 2013 Cheikh Hamidou Kane et al. This is an open access article distributed under the Creative Commons Attribution License, which permits unrestricted use, distribution, and reproduction in any medium, provided the original work is properly cited.

\begin{abstract}
The installation of a purification unit since 2008 in the village of Thiakhar has improved the physico-chemical and bacteriological quality of the water supply. However about $55 \%$ of the raw water comes out of the unit as discharges (approximately $14 \mathrm{~m}^{3}$ per day) highly concentrated in fluoride and chloride ions. Based on historical samples, we find that the volumes of water consumed together with the volumes of water discharged are increasingly significant from year to year. The storage of waste water is carried out in a septic tank connected to a leaking cesspool sink. Significant excesses of these discharges are visible on the site and a flow of concentrate is observed creating a puddle of water that attracts birds and straying cattle. The study describes the following substantial impacts on the natural and human environment: 1) contamination of groundwater, 2) soil salinization 3), impact on flora and fauna, 4) impact on health. The study concludes by identifying measures to mitigate the negative impacts related to the discharges and by proposing alternative solution.
\end{abstract}

Keywords: Drinking Water Treatment; Quality; Discharges; Pollution Mitigation

\section{Introduction}

In order to fight against poverty and achieve the Millennium Development Goals, the Senegalese government has initiated major rural hydraulic programs for drinking water for people and livestock. In this context and to achieve these goals, Senegal, has been organizing for several years large village and pastoral water supply programs in the area of the groundnut basin.

The majority of boreholes used in the study area have chemical parameters that exceed the guidelines set by the WHO for particular levels of fluoride, chloride and sodium etc.

Therefore, as part of the dynamics of the fight against poverty population in rural areas, the improvement project and building water points in the groundnut basin (PARPEBA) were set up in the village of Thiakhar-a reverse osmosis pilot water purification unit. This unit is aimed at improving the physico-chemical quality of the supplied water by significantly reducing the levels of fluoride and salt $(\mathrm{NaCl})$.
Since its installation in 2008 , the unit that provides people a good physico-chemical and bacteriological quality water is experiencing significant constraints such as: 1) the discharge into the immediate environment of an effluent containing amounts of fluoride and significant salts, 2) the supply of water to all villages polarized by drilling of Thiakhar from one distribution point in the village center of Thiakhar, making access very difficult for populations, 3) the lack of environment pollution risks related to the discharges (concentrate) from the water treatment, etc.

This study aims at assessing the negative impacts related to discharges from the purification unit on the environment in order to better understand these different elements.

\section{Presentation of the Water Purification Unit}

The purification unit of Thiakhar is reverse osmosis which is a method for water treatment consisting of three 
steps (Figure 1):

- The pre-treatment;

- Treatment or reverse osmosis itself;

- The post-treatment.

Pretreatment is an initial filtering process where water passes through a particulate filter (prefilter) which retains any solid particles in the water which could obstruct the reverse osmosis membrane. The water is then routed to a carbon filter that traps minerals and contaminants.

Water is transferred under pressure to the reverse osmosis module in which only clean water can pass through the pores of the membrane $\left(12 \mathrm{~m}^{3}\right.$ per day of processed water). Impurities that cannot pass through the membrane are eliminated in the exhaust pipe and forming the discharges of the system ( $55 \%$ of the raw water) representing approximately $14 \mathrm{~m}^{3}$ per day of release highly concentrated in fluoride ions and chlorides.

Post-processing is provided by a system of radiation Ultra-violet (UV) which eliminates bacterial contamination and improves the taste of water.

At Thiakhar treated water is sent to a tank ground before being sold to the people and the concentrate or discharges (Figure 2) is piped to a septic tank connected to a cesspool sink where water seeps into soil.

\section{Methodology}

The approach was to consult all the literature including hydrogeological and geophysical studies in the study area [1-4].

The documentation phase was completed by a field mission which involved a campaign of chemical sampling on an experimental site named Thiakhar. So, in situ physicochemical analyzes were performed on site (measures $\mathrm{pH}$, conductivity and temperature) and water samples were collected for laboratory analysis of water chemistry in the Department of Geology at the University Cheikh Anta Diop for physico-chemical analyzes on complete 18 water samples. Furthermore, control analyzes on four samples were made in laboratory analysis and testing of the Higher Polytechnic School of Dakar.

The results of chemical analyzes has allowed the hydrochemical characterization of raw water drilling, water that is treated and discharged by by the purification unit. Also an estimate of the volume of water treated and discharged was made based on the records available from April 11, 2008 (date of initiation of the purification unit) April 30, 2012.

\section{Hydrogeoligical situation}

The groundwater resources are the only source of water for people in Diourbel.

More specifically within the scope of Thiakhar and

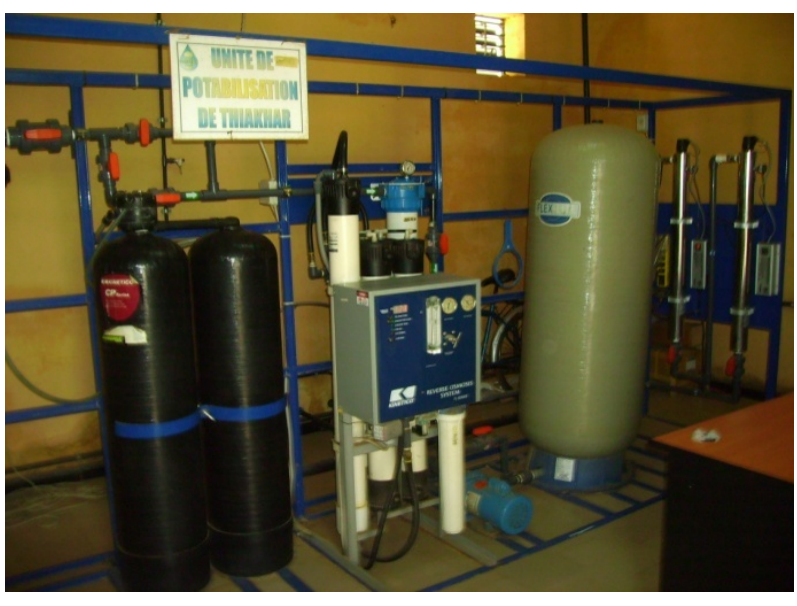

Figure 1. Purification unit.

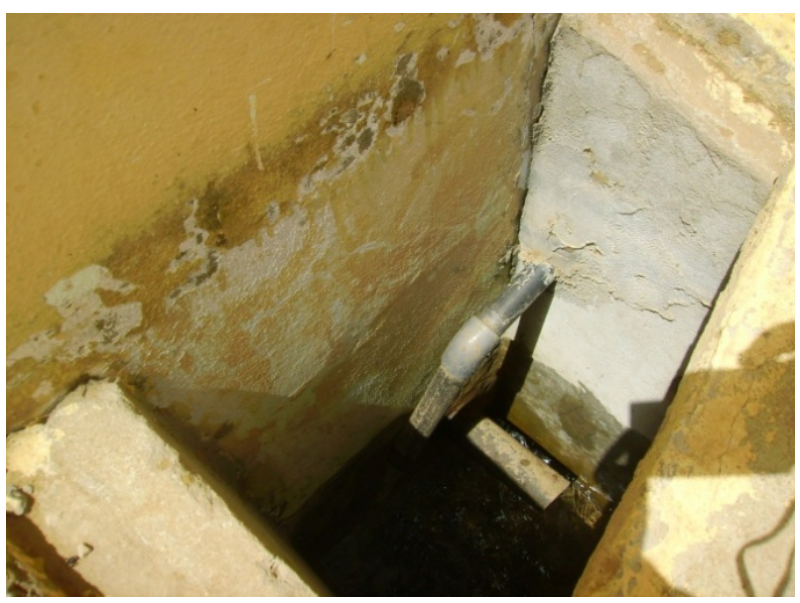

Figure 2. View of the discharge.

surroundings the existing wells and drilling capture, for the first ones, the sheet of water of the Eocene, very productive in this area to be exploited and otherwise, for the second one, the sheet of water Maastrichtian localized between 200 and 500 meters.

Set up in 1986 with a 315-meter depth, the drilling of Thiakhar operates Maastrichtian aquifer. Originally, it was passing $15 \mathrm{~m}^{3} / \mathrm{h}$ in a tank floor raised $50 \mathrm{~m}^{3} / 2 \mathrm{~m}$ and provided an average water quality (fluorine: $2 \mathrm{mg} / \mathrm{l} \mathrm{Chlo-}$ ride: $324 \mathrm{mg} / \mathrm{l})$. Following the installation of new pumping equipment in 2004 and the increase of samples, the chemical mineralization has significantly increased (fluorine: $2.4 \mathrm{mg} / \mathrm{l}$ Chloride: $617 \mathrm{mg} / \mathrm{l}$ ).

In 2007, the drilling of Thiakhar was rehabilitated and tested at a receipt pressure of $63.22 \mathrm{~m}^{3} / \mathrm{h}$ and was then connected to a water tower of $150 \mathrm{~m}^{3} / 20$ serving 48 items on a linear of $31 \mathrm{~km}$ in 19 polarized villages (Figure 3). The new created water tower was connected to the reservoir on the existing ground giving a total capacity of $150 \mathrm{~m}^{3}$. The results of chemical analyzes of water from the drilling are listed in the paragraphs below. 


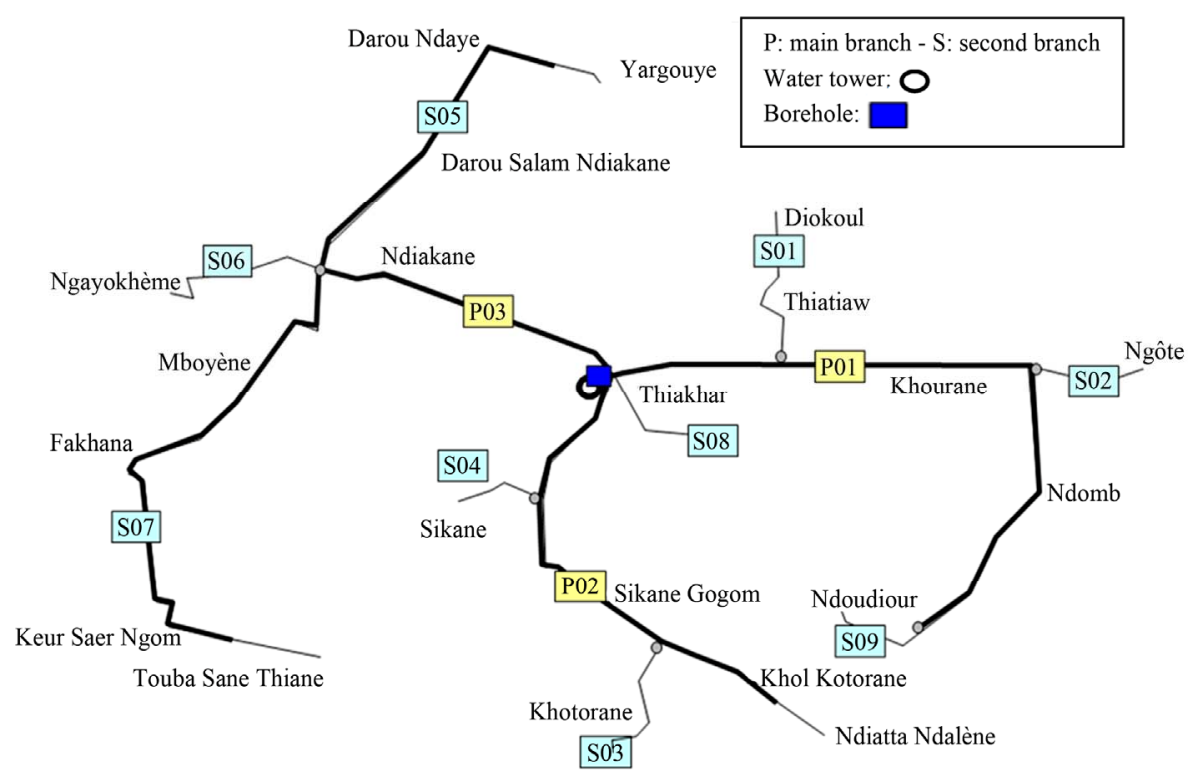

Figure 3. Presentation of the site Thiakhar.

\section{Results}

\subsection{The Raw Water from the Water Sheet Maastrichtian}

The results of chemical analyzes of the raw from the drilling of Thiakhar (Table 1) show water fluoride and chloride levels relatively high and respectively equal to $3.53 \mathrm{mg} / \mathrm{l}$ and $612.37 \mathrm{mg} / \mathrm{l}$. The origin of fluoride does not seem to be autochthonous to Maastrichtian sedimentation, but probably come from the migration of fluids from the overlying formations. The salinity of the water is probably due to the presence of ancient marine waters that constitute an area of salt water stagnation deeply "rooted" in dense brines.

The analysis of these results during these two periods (Table 1, Figure 4) confirms that the waters have drilling Thiakhar contents chlorides and fluorides that far exceed the guidelines set by the WHO (in logarithmic scale in the figure to better show the trends). In addition, the dry residue which measures the total dissolved solids (TDS) indicates a very high mineralization that exceeds the concentration limit generally accepted for the distribution of drinking water. It is the same for sodium and electrical conductivity (EC), which reflect the high salinity of untreated waters from the drilling of Thiakhar waters.

According to the Senegalese standards in force, any work intend for feeding the population among from which water has higher concentration of fluoride than $3 \mathrm{mg} / \mathrm{l}$ must be closed, without exception. Note, however, that the implementation of these standards has never been enforced by the government.

Furthermore, the implementation of such a measure would result in the closure of more than 220 works (15\% of the national park) All which Contribute $92 \%$ of the
Table 1. Results of the chemical analyzes of the Thakhar drilling raw water collected in 2009 and 2012 [5].

\begin{tabular}{|c|c|c|c|}
\hline \multirow{2}{*}{ Sample } & \multirow{2}{*}{ WHO guideline } & \multicolumn{2}{|c|}{ Raw water } \\
\hline & & 2009 & 2012 \\
\hline $\mathrm{T}^{\circ} \mathrm{C}$ & - & 36.7 & 33 \\
\hline pH (Labo) & $6.5-9$ & 7.59 & 7.47 \\
\hline CE (Labo) & $<1000 \mu \mathrm{s} / \mathrm{cm}$ & 2650 & 2835 \\
\hline $\mathrm{F}^{-}$ & $<1.5 \mathrm{mg} / \mathrm{l}$ & 3.31 & 3.53 \\
\hline $\mathrm{HCO}_{3}^{-}$ & - & 549 & 549 \\
\hline $\mathrm{Cl}^{-}$ & $<200 \mathrm{mg} / 1$ & 600.97 & 612.37 \\
\hline $\mathrm{NO}_{3}^{-}$ & $<50 \mathrm{mg} / 1$ & - & 1.71 \\
\hline $\mathrm{SO}_{4}^{2-}$ & $<250 \mathrm{mg} / 1$ & 65.49 & 63.24 \\
\hline $\mathrm{Na}^{+}$ & $<150 \mathrm{mg} / \mathrm{l}$ & 610.96 & 621.47 \\
\hline $\mathrm{K}^{+}$ & $<12 \mathrm{mg} / \mathrm{l}$ & 11.93 & 18.76 \\
\hline $\mathrm{Mg}^{2^{+}}$ & $<50 \mathrm{mg} / \mathrm{l}$ & 6.4 & 2.55 \\
\hline $\mathrm{Ca}^{2^{+}}$ & $<50 \mathrm{mg} / \mathrm{l}$ & 10.44 & 11.81 \\
\hline TDS (RS) & $<750 \mathrm{mg} / 1$ & 2280 & 2186 \\
\hline
\end{tabular}

output of water for feeding a population estimated at nearly 700,000 people, distributed in 251 villages.

\subsection{The Waters of the Maastrichtian Treated and Discharged from the Purification Unit}

Chemical analyzes of water from the reverse osmosis unit pertaining concerned two water samples from the treated water drilling and water discharge or concentrate. Chemical. 


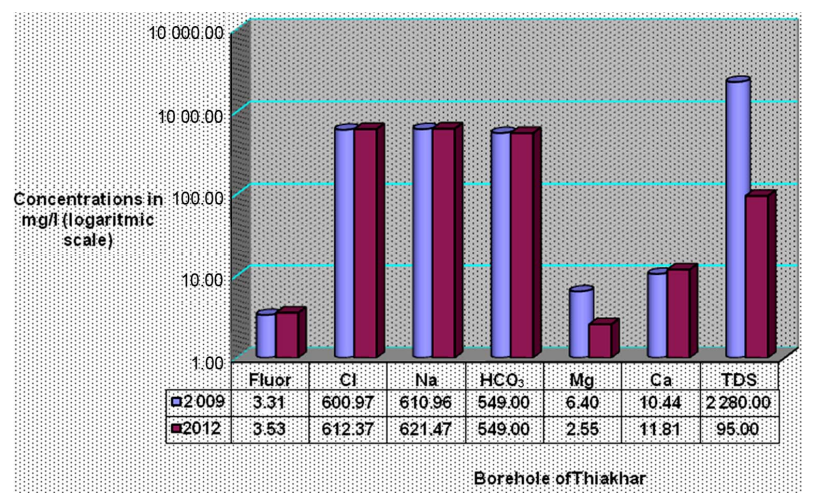

Figure 4. Variation of chemical parameters ( $\mathrm{mg} / \mathrm{l})$ of water from drilling Thiakhar between 2009 and 2012.

The results of the chemical Analyzes are shown in the figure below:

Note: The contents of fluoride and magnesium which are virtually trace for treated water were reduced to 1 $\mathrm{mg} / \mathrm{l}$ so that it cuts the logarithmic axis of the figure below:

The interpretation of these results shows for:

- Treated water: the results of chemical analysis show a very significant decrease in major constituent elements of the composition of the water (Figure 5). We finally obtained chloride and fluoride levels below the guidelines set by the WHO. In general there is a decrease of the content of other chemical parameters including calcium and magnesium ions whose concentrations represent less than $2 \mathrm{mg} / \mathrm{l}$. It is generally accepted that calcium ions and magnesium are important elements of water and have direct and indirect impact on health in both direct and indirect. Indeed, it is often reported that the optimum $\mathrm{Ca}$ and $\mathrm{Mg}$ levels in drinking water should be in the following ranges: 20 to $30 \mathrm{mg} / \mathrm{l}$ for $\mathrm{Ca}$ and 40 to $80 \mathrm{mg} / \mathrm{l}$ for $\mathrm{Mg}$ and about 200 to $400 \mathrm{mg} / \mathrm{l}$ for water hardness. But opinions are highly divided and unfortunately, over the last two decades research has paid little attention to the beneficial or protective substances drinking water. Thus, it should conduct further study to determine if there is place to add the necessary additives that increase if need levels of calcium and magnesium. This is all the more necessary that this method is not specific to an ion but causes a loss of many other useful substances. This issue could nevertheless be easily solved by installing a bypass remineralization over the existing installation [6];

- The waste: Based on the results of chemical analyzes, waste water is water with very high salinity and very busy (dry residue: $4070 \mathrm{mg} / \mathrm{l}$ in 2009 and $3934 \mathrm{mg} / \mathrm{l}$ in 2012). The results of the chemical analysis show high levels of fluorides and chlorides equal respectively equal to $7.12 \mathrm{mg} / \mathrm{l}$ and $1042.29 \mathrm{mg} / \mathrm{l}$.

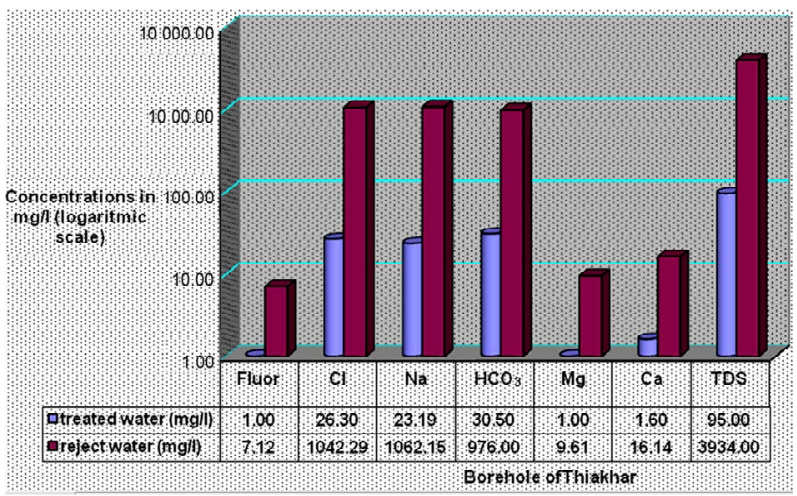

Figure 5. Chemical analyzes of water treated and discharged water (2012) from the purification unit.

\subsection{Estimated Water Consumption Target Populations Treated and the Volume of Water Discharged from the Water Purification Unit}

The volume of water discharged is $55 \%$ of the raw water volume, in other words about 100 liters of raw water from the borehole 45 liters of treated water is collected. From April 11, 2008 (date of initiation of the purification unit) to April 30, 2012, the estimated daily treated water consumption of the target populations and the daily water discharged volume from the water purification unit are shown in the Table 2.

At the discretion of the estimated volumes (see Figure 6), the volume of consumed water and accordingly the volume of discharged water are gradually becoming more important than one year to another.

\section{Impact of Reject Water Environmental Site}

The data obtained from the lithostratigraphic of Thiakhar's drilling show that the outermost water sheet captured by the existing wells in the studied perimeter is contained in the calcareous marl and limestone formations of the Eocene characterized by very low permeability due to the presence of marl. The nature of crossed formations from the surface of the ground up to limestone consists essentially of sand intercalated with laterite, limestone, clay and lignite sandy clay Quaternary and Continental Terminal.

The nature of the overlying layers including the presence of marl, laterite, limestone and sandy clays and dynamic levels of the closest site generally exceeding 25 meters deep gives them a low permeability which would limit the infiltration of discharges from the treatment purification unit to the uppermost aquifer. This negative impact is small and localized.

During field investigations, it was observed that the waste water is discharged into a septic tank connected to 
Table 2. Estimate consumption of treated water and the volume of waste water discharged.

\begin{tabular}{cccc}
\hline Year & Raw water & Discharged water & Treated water \\
\hline $\begin{array}{c}\text { April 11 2008 to } \\
\text { December 31, 2008 }\end{array}$ & $925 \mathrm{~m}^{3}$ & $508.75 \mathrm{~m}^{3} /$ year & $416.25 \mathrm{~m}^{3} /$ year \\
& & $1.93 \mathrm{~m}^{3} /$ day & $1.58 \mathrm{~m}^{3} /$ day \\
2009 & $2131 \mathrm{~m}^{3}$ & $1172.05 \mathrm{~m}^{3} /$ year & $958.95 \mathrm{~m}^{3} /$ year \\
& & $3.21 \mathrm{~m}^{3} /$ day & $2.63 \mathrm{~m}^{3} /$ day \\
2010 & $4056 \mathrm{~m}^{3}$ & $2330.80 \mathrm{~m}^{3} /$ year & $1825.20 \mathrm{~m}^{3} /$ year \\
& & $6.39 \mathrm{~m}^{3} /$ day & $5.00 \mathrm{~m}^{3} /$ day \\
2011 & $6475 \mathrm{~m}^{3}$ & $3561.25 \mathrm{~m}^{3} /$ year & $2913.75 \mathrm{~m}^{3} /$ year \\
& & $9.76 \mathrm{~m}^{3} /$ day & $7.98 \mathrm{~m}^{3} /$ day \\
2012 & $1901 \mathrm{~m}^{3}$ & $1045.55 \mathrm{~m}^{3} /$ year & $855.45 \mathrm{~m}^{3} /$ year \\
(until end 2012) & & $8.64 \mathrm{~m}^{3} /$ day & $7.07 \mathrm{~m}^{3} /$ day \\
\hline
\end{tabular}

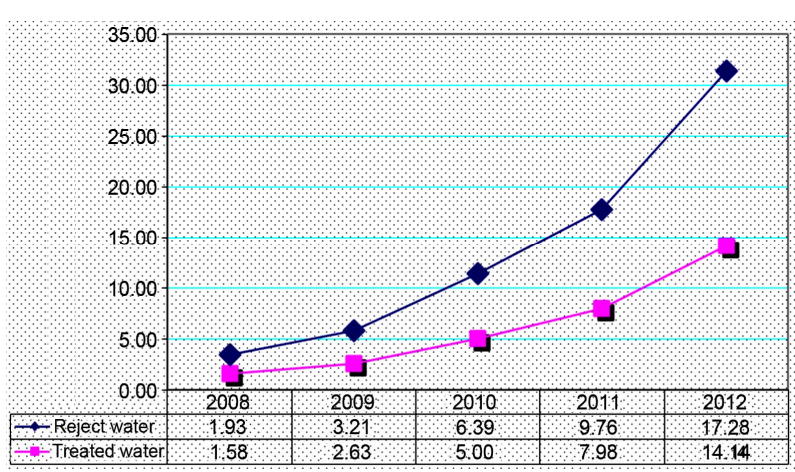

Figure 6. Estimate of the volume of treated and discharged water.

a leaking cesspool where water seeps into the ground (Figure 7).

It was also observed that the full pit left overflow discharges creating a pool that flows to the nearest concessions (Figure 8).

These water discharges also attract birds and roaming livestock and thus constitutes a real threat to the environment of the site (Figure 9).

The overflow of these discharges could cause salinization of the site, that is to say, increasing the salt content of the soil. Water, even gentle, contains dissolved salts. The contribution year after year, even lightly salted water, will increase the amount of salt in the soil, the water is absorbed by plants, soil evaporates but the salt remains.

Sodium ions, chloride and fluoride contained in the discharged water can lead to a long-term or even irreversible contamination of soil. Sometimes they can get into the food chain (earthworms, bird, human) by storage in soil ecosystems (earthworms). The accumulation of sodium ions will gradually lead to the formation of sodic soils of very low fertility.

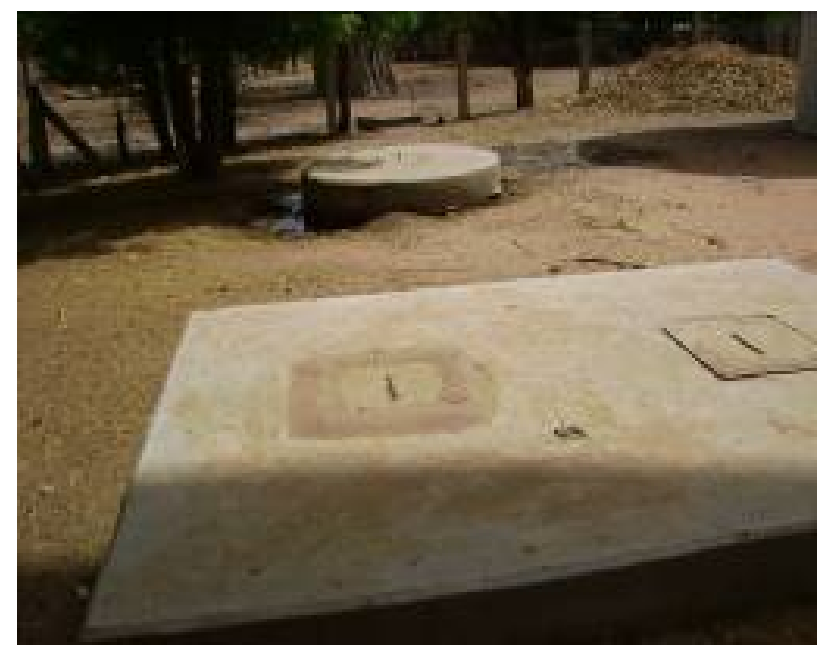

Figure 7. Tank and soakaway e.

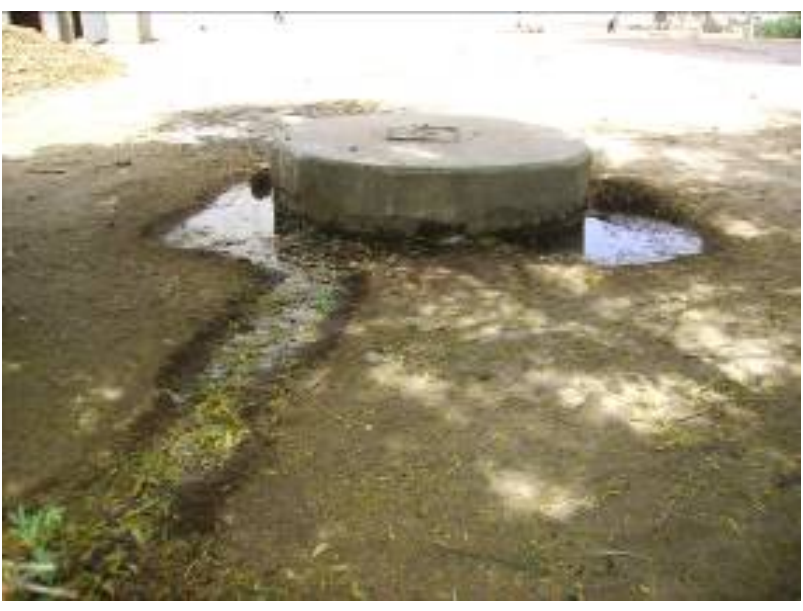

Figure 8. Overflow the pit and creating puddles.

High concentrations of salts in the soil water reduce the ability of plants to absorb water and nutrients which exposes plants to drought conditions. At low concentrations, the salts are not harmful and may in fact provide important nutrients to the plant. However, with increasing salt concentrations, the effect of drought can be so pronounced that even the salt-tolerant plants cannot grow.

Sensitivity to salt varies according to the type of crop. For example, the salt-sensitive crops such as edible beans are assigned to lower salinity levels and to a greater extent than cereals and oilseeds. Soils with low salinity affect the growth and yield of most crops, and moderate to high salinity reduced by at least $50 \%$ the yield of most grains and oilseeds.

Salinity degree (amount of soluble salts) of the soil has a significant impact on the species or varieties that can be grown successfully.

For the specific case of fluorine in the soil, it can accumulate in plants. The amount absorbed by plants depends on the type of plant, the type of soil and the form 

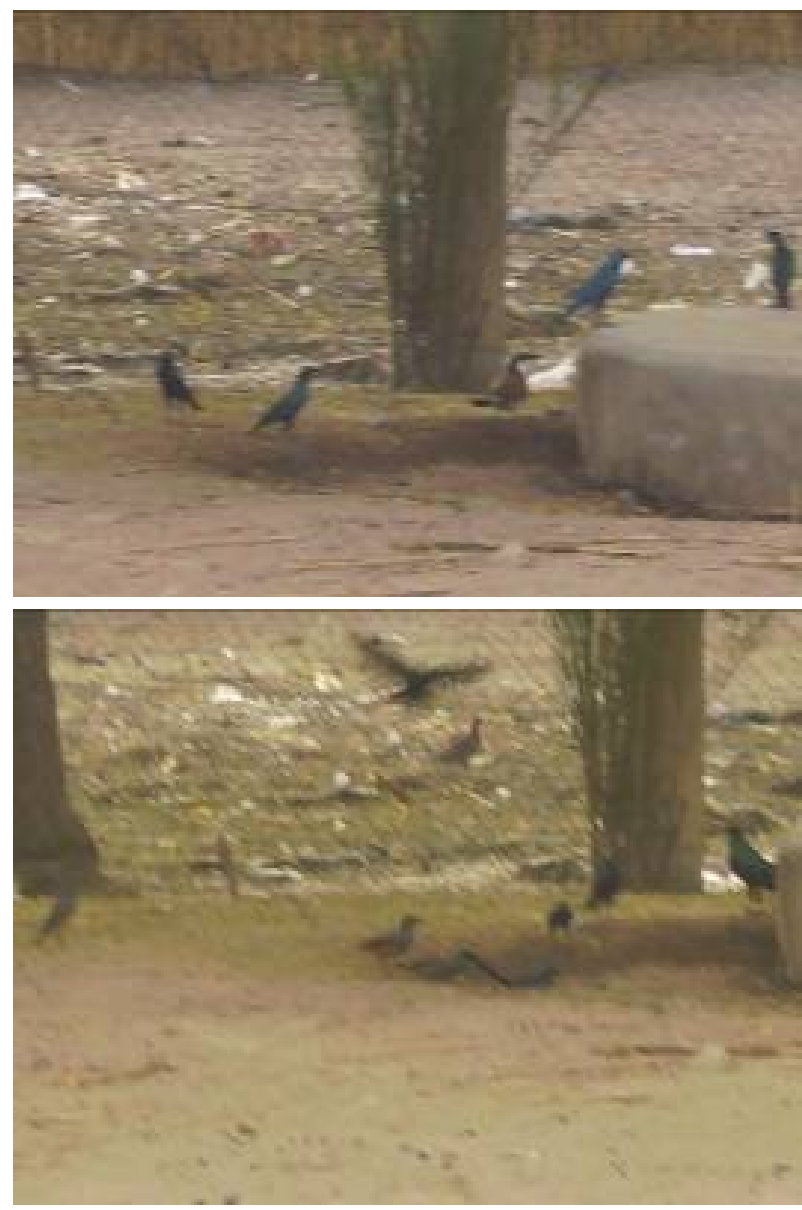

Figure 9. Presence of birds that come to drink water discharges.

and amount of fluorine present in the soil. For plants that are sensitive to fluoride exposure, even low concentrations can cause damage and hinder their growth.

Animals that eat plants containing fluorine can accumulate significant amounts in their bodies. Fluoride accumulates first in the bones. An animal exposed to high concentrations of fluoride caries and suffer bone loss. Chronic exposure of animals is a harmful risk to animal health. This risk is even higher than the backwaters are very attractive in the dry season for wildlife in the area.

Mismanagement of discharges at the site can induce an effect on the health of residents. Indeed, in the case of overflow the pit, discharges flow around the pit and create a pool which leads over time to:

- The development of disease vectors related to water especially mosquitoes and snails;

- The development of water-related diseases (malaria, diarrhea);

- The proliferation of insects and molluscs vectors and intermediate hosts of various parasitic diseases.

\section{Conclusions}

In conclusion, we list below in terms of activities the main measures to mitigate negative impacts of the release:

- Resize the pit in order to contain all releases;

- Properly seal the pit and wells in order to stop infiltration;

- Empty the tank regularly with vacuum trucks that will carry the water to the station nearest sewage;

- Technologically, try to reduce emissions by improving the performance of the unit;

- Avoid the spreading of waste on the surface of the ground;

- Make periodic analyzes of the level of soil contamination of the site;

- Conduct periodic campaigns disinfecting houses of disease vectors (mosquitoes, snails, etc.).

At the end of this study, we have recommended two points that are essential in our view:

- The implementation of an environmental audit in charge of the purification unit of Thiakhar. A particular attention should be paid during this audit to discharge treatment, the outcome of liquid discharges from the treatment, procedures for risk management of accidental pollution. A copy of the environmental audit should be directed to the person in charge of the environment of Thiakhar. The latter will discuss with the technical managers of the station and the consultancy firm in charge of the environmental audit of recommended corrective measures to overcome possible identified shortcomings;

- Resizing pits to contain all discharges.

\section{REFERENCES}

[1] CPGF \& HORIZON, "Geophysical Study in Car Car and Sine Valleys. Determination of Reliable Aquifers Areas69 Survey Boreholes with 400 m AB Length,” 1990.

[2] CPGF \& SONED, "Study for Water Access Improvement in 7 Inland Urban Centres. Geophysical Survey-Senegal," 1977, 20 p.

[3] DGRH, "Hydrogeologic Study in Car Car and Sine Valleys," 1991.

[4] Y. Noel, "Hydrogeologic Study of Lutetian Limestone between Bambey and Louga (2nd Phase)," Rapport 78 Dak 78 02.82p, 1978.

[5] PARPEBA, "Hydrogeologic Summary Report on Groundwater Resources in Groundnut Basin-Senegal," 2009.

[6] Hydroconseil \& Burest, “Analysis of PARPEBA Project Experiences on Water Purification and Study of Improvements and Potential Alternatives," 2009. 